\title{
Ageing in rare, chronic diseases
}

\author{
Cees Smit \\ From 5th European Conference on Rare Diseases (ECRD 2010) \\ Krakow, Poland. 13-15 May 2010
}

With more and more treatments becoming available for people with rare diseases, we encounter the issue of ageing more often. A number of patients with rare, chronic diseases have experienced a number of remarkable transitions in their lives. The most important transition is the one from no treatment at all to treatment becoming available, like in haemophilia about 45 years ago. Another transition is the one that during their lives they go from one disease to a number of diseases (co-morbidity) through the natural process of getting older or as a consequence of the side-effects of treatment.

These transitions can cause a number of problems. The first problem could be the lack of co-ordination between medical specialists and paramedical staff. The second is polypharmacy - the use of multiple medications and as a consequence of these first two problems a third problem occurs which I prefer to address as the 'fear' factor.

The 'fear' factor can be described as a lack of control when you are not able to influence or check the treatment you receive.

When more and more older persons with rare, chronic diseases will gradually transit to special care institutions for the elderly, more knowledge should be available in these institutions to deal with these new groups of patients. In this way, these patients will differ a lot from the group of elderly persons who develop comorbidity at a much older age.

Some of these issues will be addressed in this presentation, based on the personal experience of the speaker, who is also the (co-)author of several recent books on getting older with chronic diseases, like haemophilia and HIV.

Correspondence: smit.visch@wolmail.n

EGAN/NSOP, Policy advisor, Graan voor Visch 15715, Hoofddorp, 2132EM, The Netherlands

B̈oMed Central o 2010 Smit; licensee BioMed Central Ltd.
Published: 19 October 2010

doi:10.1186/1750-1172-5-S1-023

Cite this article as: Smit: Ageing in rare, chronic diseases. Orphanet

Journal of Rare Diseases 2010 5(Suppl 1):O23.

Submit your next manuscript to BioMed Central and take full advantage of:

- Convenient online submission

- Thorough peer review

- No space constraints or color figure charges

- Immediate publication on acceptance

- Inclusion in PubMed, CAS, Scopus and Google Scholar

- Research which is freely available for redistribution

Submit your manuscript at www.biomedcentral.com/submit 